\title{
Chapter 8 \\ Green Transportation: A Challenging Road to Carbon Neutrality
}

\begin{abstract}
Chinese transportation industry: Carbon emissions under upward pressure and "green premium" may stay high.

Transportation industry is of vital importance to social development. International Energy Agency (IEA) data indicates that the transportation sector contributed 9.7\% of China's carbon emissions in 2018, ${ }^{1}$ 5ppt higher than that in 1990. As GDP per capita rises, we expect the turnover rate of the transportation volume in 2060 to double, leading to a significant rise in carbon emissions in the near future.

In addition, we expect the "green premium" (i.e. the additional cost of choosing a clean energy over one that emits a greater amount of greenhouse gases like fossil fuels) of the transportation sector to be $68 \%$ in 2021, implying the cost of zero carbon emissions (i.e. the difference between the cost of using new energy and the cost of using fossil fuels) at about Rmb2.7trn, which indicates the process of decarbonization would be costly and challenging. In this chapter, we focus on the solution to China's green transportation, and aim to deduce a feasible pathway for the transportation industry to achieve carbon neutrality, potential challenges we might
\end{abstract} face, and supportive policies that are throughout the process.

Green transportation requires a combination of clean energy adoption and efficient energy consumption. While adopting clean energy is the key solution, energy conservation and emissions reduction would also help the transportation industry achieve carbon neutrality. Under neutral assumptions, we believe carbon emissions of the transportation sector will peak at 1.33 bn tonnes in 2030 and decline $77 \%$ from 1.16bn tonnes in 2019 to $261 \mathrm{mn}$ tonnes in 2060.

From a sub-sector perspective, the pathway to carbon neutrality is very clear for the segment of transportation by passenger vehicles ${ }^{2}$, we believe this segment is likely to make substantial progress in emissions reduction with China's competitive advantage in lithium-ion batteries. The segment of transportation by commercial

\footnotetext{
${ }^{1}$ There are differences in the statistics of carbon emissions from transportation industry in various databases. In previous chapters we cite data from CEADs which is lower than the carbon emissions data of the International Energy Agency and the "Second Two-Year Update on Climate Change of the People's Republic of China". We refer to data from IEA in this chapter for the purpose of international comparison.

${ }^{2}$ Passenger vehicles in this chapter refer to private cars.
} 
vehicles $^{3}$ sector is likely to achieve carbon neutrality by 2060 by relying on mid- and mini-electric trucks as well as heavy-duty fuel cell trucks. The railway transportation sector provides a clear vision for decarbonization by means of electrification. Yet it is more challenging to achieve carbon neutrality for the air and marine transportation segments, which heavily depends on technology advancement.

We will also discuss the potential technological evolution in automotive batteries and hydrogen fuel cells. In terms of technological advancements, the former has a promising pathway, whereas hydrogen fuel cell may develop beyond or under our expectations. In addition to technology advancement, achieving carbon neutrality for the transportation sector also requires policy intervention. We will give policy recommendations from both the industry level (such as separation of vehicle and battery) and technology level (such as establishing standards for hydrogen fuel cells).

The "green premium" of the transportation sector is likely to reach $2 \%$ in both 2030 and 2060, with "zero emission costs" of Rmb89.7bn and Rmb70.1bn, 97\% lower than that in 2021, indicating the viability of such emissions-reduction pathways.

Finally, we will briefly discuss the changes that autonomous driving, superhigh-speed rail and supersonic aircraft might bring to our lives. In an era of rapid technological change, we look forward to the arrival of "green transportation".

\subsection{How Far Away is Green Transportation?}

To reach the Paris Agreement's goal of capping the rise of global temperature under $1.5^{\circ} \mathrm{C}$ degrees requires extensive global cooperation to reduce carbon emissions. As the world's second largest carbon emitter among all industries needs to be more environmentally friendly. Before moving on to discuss how to achieve the ultimate goal of green transportation, the industry's current performance and historical development will be discussed in this section descibed first. We further discuss the following issues in this section: (1) sources of carbon emissions in the transportation industry; (2) current volume of carbon emissions from global transportation, and emissions structure by country and transportation segments; and (3) prediction of carbon emissions trend in the Chinese transportation industry based on past experience from the US and Europe.

\subsubsection{Sources of Carbon Emissions in the Transportation Industry}

Steam engines were invented during the first Industrial Revolution and were used for marine and rail transportation in the early nineteenth century, signaling the start of carbon emissions in the transportation industry. The internal combustion engines

\footnotetext{
${ }^{3}$ In this chapter, commercial vehicles (CV) refer to trucks unless stated otherwise.
} 
invented during the second Industrial Revolution led to the emergence of cars in 1887 and airplanes in 1903, accelerating carbon emissions in the transportation industry. Subsequently, improved transport infrastructure made transportation and travel more convenient. For example, the total length of railways around the world has increased by about $600,000 \mathrm{~km}$ over the past century, which is nearly double the length in the previous century, and the global ownership of aircrafts for aviation expanded from zero to about 450,000 at present. The market for transportation via roads, aviation, rail and marine has entered the era of all-round development, which has led to a large amount of carbon emissions.

\subsubsection{Current Amount of Global Carbon Emissions from Transportation}

IEA data shows that the world emitted 33.5bn tonnes of carbon in $2018(+63 \%$ from 1990), with $24.6 \%$ or $8.26 \mathrm{bn}$ tonnes from the transportation industry (Fig. 8.1), second only to the power generation industry $(41.7 \%)$. Moreover, the $24.6 \%$ proportion expanded $2.2 \mathrm{ppt}$ from 1990, as carbon emissions from the transportation industry rose at a $2.1 \%$ CAGR over 1990-2018, exceeding the 1.8\% CAGR of overall global emissions.

This section will analyze changes in global carbon emissions within the transportation industry, by segment and country (starting from 2008 due to data availability).

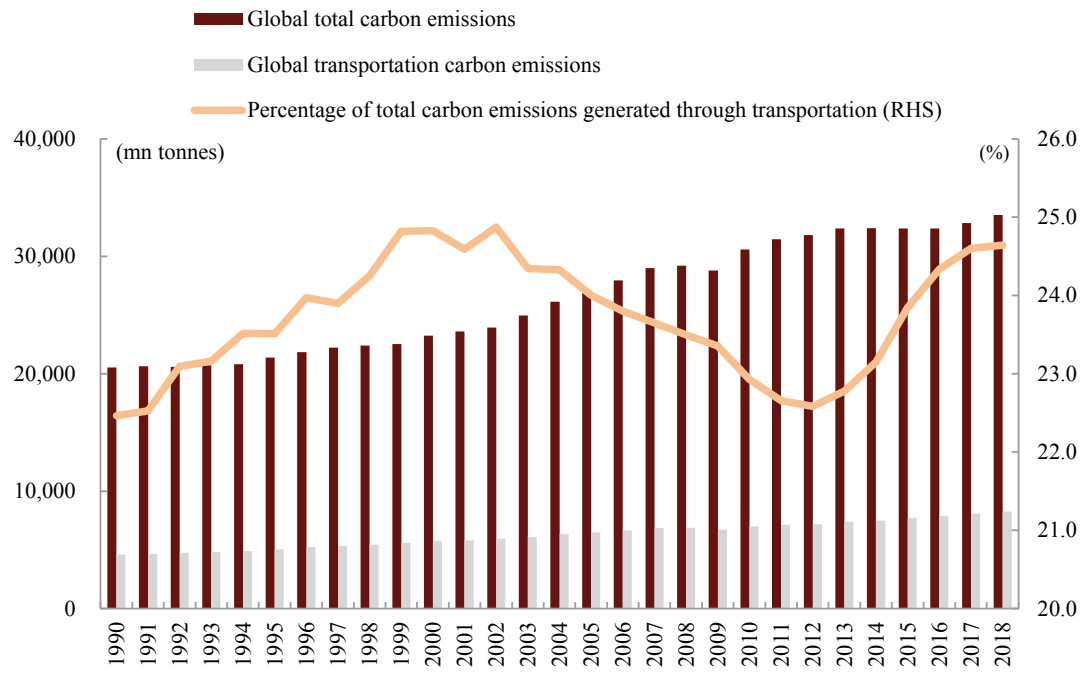

Fig. 8.1 Global carbon emissions from transportation. Source IEA, CICC Research 


\subsubsection{Type of Transportation: Road Transport is the Largest Source of Emissions, While Aviation's Emission Volume Growth is the Highest}

Total emissions volume: In 2018, road transport emitted 6.1bn tonnes of carbon, accounting for $74.5 \%$ of global emissions from the transportation industry. The share of aviation and marine transportation stood at $11.7 \%$ and $10.5 \%$, while the proportion of railway transportation was only $1.1 \%$ due to the wide adoption of electrification.

Incremental emissions volume: The world's incremental carbon emissions from transportation totaled $1.4 \mathrm{bn}$ tonnes in $2008-2018$, with $78 \%$ or $1.1 \mathrm{bn}$ tonnes from road transportation. Carbon emissions from aviation recorded the highest growth among all modes of transport-expanding at a 3.4\% CAGR in 2008-2018 and increasing about 200mn tonnes in 2008-2018 - and accounted for $14 \%$ of the global incremental emissions from transportation. The world's aviation passenger turnover rate increased at a 5.9\% CAGR, which is a major driver for the growth in carbon emissions from aviation.

\subsubsection{Countries: US Contributed Most to Global Carbon Emissions from Transportation, while Emissions from Chinese Transportation Industry Had the Highest Growth}

Total carbon emissions volume: The transportation industry in the US, EU and China emitted $1.81 \mathrm{bn}, 1.24 \mathrm{bn}$ and $1.12 \mathrm{bn}$ tonnes of carbon respectively in 2018 , accounting for $21.9 \%, 15.0 \%$ and $13.6 \%$ of global emissions from transportation.

Incremental emissions volume: Carbon emissions from transportation in China had the highest growth rate, while emissions from transportation in the EU and the US trended downward. Carbon emissions from transportation in China increased $580 \mathrm{mn}$ tonnes in 2008-2018, accounting for $41 \%$ of global incremental emissions. Of the 580mn tonnes, $88 \%$ or $510 \mathrm{mn}$ tonnes were from road transport, as Chinese personal vehicle (PV) ownership surged $557 \%$ YoY and road cargo turnover soared $177 \%$ YoY during 2008-2018. In contrast, carbon emissions of transportation in the EU and the US in 2018 contracted about $68 \mathrm{mn}$ and $200 \mathrm{mn}$ tonnes from 2008 , implying a CAGR of $-0.2 \%$ and $-1.1 \%$.

\subsubsection{Have Carbon Emissions from Transportation Peaked in EU and US? What Experiences Can China Draw upon?}

Carbon emissions from transportation have not yet peaked EU and US. The emissions from transportation declined after hitting highs of 1.3bn tonnes in the EU and 2bn tonnes in the US in 2007. However, the emissions in both EU and US rebounded 
later. According to the latest available data, carbon emissions from transportation in EU and US both recovered to more than $90 \%$ of their respective highs seen in 2007. Whether the emissions have peaked still depends on the adoption rate of new energy.

\subsubsection{Experiences that China May Draw upon from the EU and US}

First, we do not think the transportation industry can reach peak carbon emissions unless emissions from road transportation have peaked. In 2018, road transportation contributed $86 \%$ and $72 \%$ of the total transportation sector's carbon emissions in the US and EU. Emissions in these two regions both temporarily peaked after road transportation's emissions peaked.

Second, the transport turnover trend largely moves in tandem with carbon emissions. As mentioned earlier, after peaking temporarily, the emissions from transportation in EU and US declined at first and then picked up again. Partially it is driven by the fact that both cargo and passenger transport turnover contracted after the financial crisis in 2007 and did not grow again until 2013 when the economies started to recover. In other words, transport turnover plays an important role in affecting the total carbon emission from transportation.

Third, the decline in carbon emissions from transportation relies on the enhancement in energy consumption efficiency, and the application of new energy and new technologies can also accelerate the enhancement. We noticed that per-unit energy consumption of each mode of transportation declined at an accelerated pace in both the US and EU after 2007. For example, per-unit energy consumption in the US PV-based transport sector dropped $1.1 \%$ in a decade after 2007 , faster than the $0.6 \%$ decline seen in the decade before 2007. This trend, to a large extent, is driven by applications of new energy and new technologies.

\subsection{The Difficulties for Chinese Transportation Industry to Achieve Carbon Neutrality Measured by the "Green Premium"}

This section focuses on carbon emissions from the Chinese transportation industry, and uses the "green premium" to calculate the cost of zero carbon emissions for it. We notice that carbon emissions from transportation might rise notably in China, and the high "green premium" indicates the industry faces great difficulties in achieving carbon neutrality. 


\subsubsection{Carbon Emissions from Transportation Rise Notably in China}

In 2018, IEA data shows that transportation contributed $9.7 \%$ of China's carbon emissions (see Fig. 8.2), still well below the global share of $24.6 \%$. Nevertheless, carbon emissions from transportation expanded at an 8.3\% CAGR in China during 1990-2018, much higher than the $2.1 \%$ growth of global emissions from transportation and the $5.6 \%$ growth of China's total carbon emissions. The share of carbon emissions from transportation in China expanded 5ppt in this period. As GDP per capita rises, transportation demand is expected to grow faster and the total carbon emissions of transportation will increase notably in China. It remains unclear when the country's transportation industry will achieve carbon neutrality. However, the predicting timetable by analyzing its carbon emission structure and emission growth drivers in each sector.

Road transport, aviation, marine transportation, and railways contributed $83.4 \%$, $9.8 \%, 5.4 \%$ and $1.3 \%$ of China's total carbon emissions from transportation in 2018 (see Fig. 8.3). Based on the experience in the US and Europe, we will focus on road transportation and aviation sectors when analyzing emissions from the Chinese transportation industry.

There are two sub-sectors of the road transportation: PV-based transport and CV-based transport.

The rising PV ownership and the penetration of alternative fuel vehicles strongly influence the amount of carbon emission of the PV-based transportation. In China,

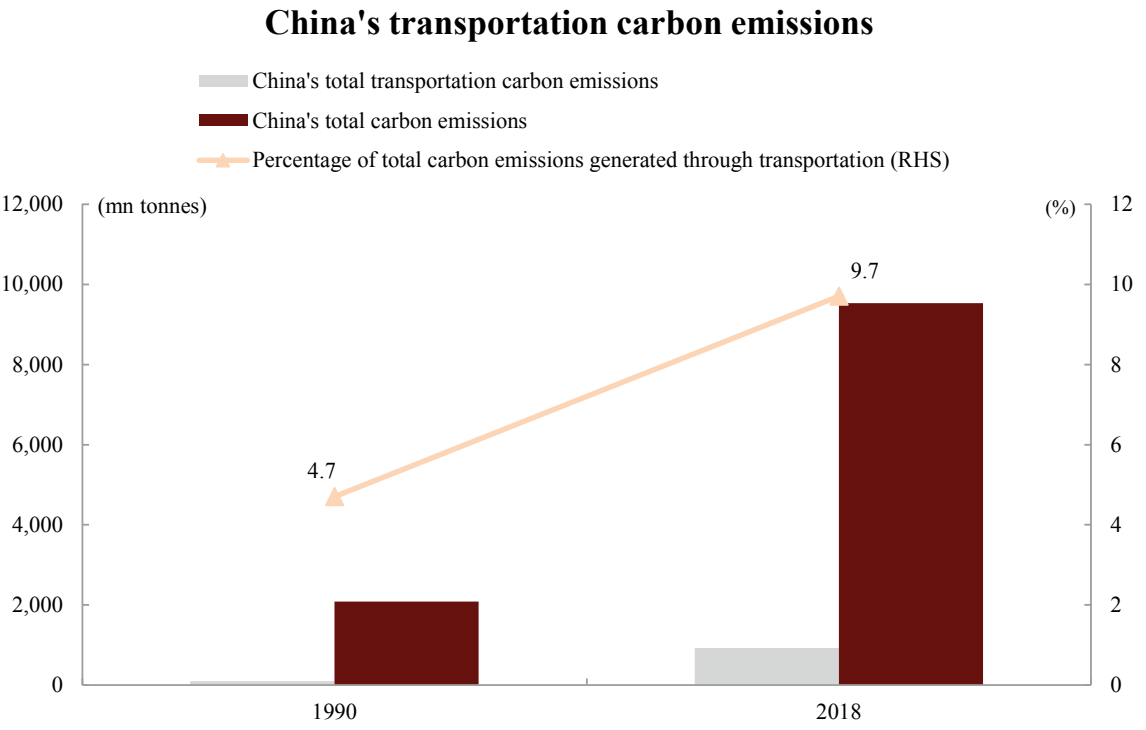

Fig. 8.2 Carbon emissions from transportation in China. Source IEA, CICC Research 


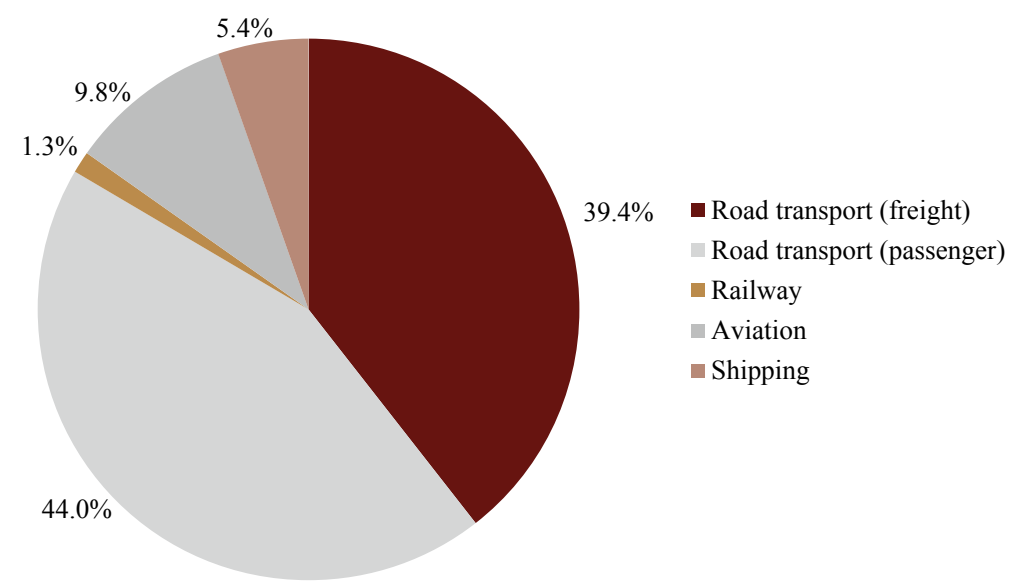

Fig. 8.3 Chinese transportation industry's emissions structure in 2018. Source IEA, CICC Research

the PV ownership still has large upside potential. Wind Info data shows that the ownership per 1,000 persons in China was only about $1 / 6$ and $1 / 5$ of the levels in the US and Europe in 2019. Meanwhile, China leads the world in NEVs. We believe the rising NEV penetration and increasing PV ownership will both affect the country's PV-based transport carbon emission.

The changes to freight transport structure and the timing of mass adoption of alternative fuel CVs hold the key to the carbon emissions from CV-based transport. In our view, alternative fuel CVs will first enter the market with light-duty trucks, then mid-duty trucks, and eventually heavy-duty trucks, to gradually reduce carbon emissions of CV-based transport. We believe China's freight transport structure will change as freight owners shift away from road transport to railway and waterway. In addition, efforts in energy saving and emissions reduction such as improving fuel efficiency and digitalization applications are equally important before massive penetration of alternative fuel CVs.

The aviation sector also merits attention. It is the second largest carbon emitter in the transportation industry, and its emission growth remains high. Decarbonization of the aviation sector is challenging, and the key lies in jet fuel replacement by new energy. We predict aviation transport volume will continue to grow. Wind Info data shows that the number of per-capita air trips in China was only 1/7 and 1/5 of the levels in the US and EU in 2018. Due to its long transporting distance, heavy energy consumption and immature zero-carbon technologies, decarbonization in the aviation sector is challenging.

The marine transportation sector faces challenges down its road to decarbonization. It contributed only $5.4 \%$ of carbon emissions from the transportation industry in 2018, and its emissions CAGR remained low at $1.4 \%$ in the past decade. However, decarbonization is challenging due to long transport distance and high vessel tonnage.

The railway sector faces a visible pathway of decarbonization via electrification. Electrification rate in this sector expanded 36ppt in the past decade to reach $72 \%$. 
We believe the railway sector will achieve zero carbon emissions if electrification system is fully adopted.

\subsubsection{The High “Green Premium” Indicates Decarbonization in the Transportation Industry Is Costly and Challenging, and Requires a Combination of Technological Innovation and Favorable Policies}

As mentioned earlier, the "green premium" refers to the additional cost arising from using new energy as a percentage of the cost of using fossil fuels, and the cost of zero carbon emissions is the additional cost that needs to be paid to achieve zero carbon emissions.

Take PV-based transport an example. The "green premium" in the PV-based transport sector is defined as follows: (clean electricity cost-gasoline cost)/gasoline cost. We estimate that PV's clean electricity cost per $100 \mathrm{~km}$ is $60 \%$ lower than that of gasoline cost in 2021. However, as pure electric PVs are more expensive than traditional fuel PVs, we think calculating based on lifecycle cost is more reasonable. Assuming similar specifications and torque, we estimate that the lifecycle cost of a traditional fuel PV is about Rmb0.57/km, versus Rmb0.68/km of a pure electric PV. The PV industry's energy consumption cost will increase from Rmb2.3trillion at present to Rmb2.7trillion after traditional fuel PVs are completely replaced. In other words, the "green premium" is about $18 \%$. For more details, please refer to Table 8.1.

The "green premium" of the aviation sector is defined as (hydrogen cost-jet fuel cost)/jet fuel cost. Although calculation based on lifecycle cost is more reasonable,

Table 8.1 We estimate that the transportation industry's "green premium" in 2021 is around $68 \%$

\begin{tabular}{l|l|l|l|l}
\hline $2021 \mathrm{E}$ & $\begin{array}{l}\text { Current energy } \\
\text { cost (Rmb bn) }\end{array}$ & $\begin{array}{l}\text { Alternative energy } \\
\text { cost (Rmb bn) }\end{array}$ & $\begin{array}{l}\text { Zero carbon } \\
\text { emission cost } \\
(\mathrm{Rmb} \text { bn })\end{array}$ & $\begin{array}{l}\text { Green premium } \\
(\%)\end{array}$ \\
\hline $\begin{array}{l}\text { Road transport } \\
\text { (freight) }\end{array}$ & 1,519 & 3,454 & 1,935 & 127 \\
\hline $\begin{array}{l}\text { Road transport } \\
\text { (passenger) }\end{array}$ & 2,267 & 2,685 & 418 & 18 \\
\hline Railway & 41 & 29 & -12 & -29 \\
\hline Aviation & 72 & 317 & 245 & 343 \\
\hline Shipping & 28 & 116 & 88 & 319 \\
\hline Total & 3,926 & 6,601 & 2,675 & 68 \\
\hline
\end{tabular}

Note We calculate zero carbon emission cost of PV- and CV-based transport sectors based on lifecycle cost. Source CICC Research 
the "green premium" is calculated with only energy consumption cost, given unavailable data on the cost of newly or renovated hydrogen-powered planes. We calculate the "green premium" is $343 \%$, with total jet fuel cost at Rmb71.5bn and hydrogen consumption cost at Rmb316.7bn.

Generally speaking, the transportation industry's zero carbon emission cost in 2021 is estimated to be around Rmb2.7trn, implying a "green premium" of $68 \%$, which suggests a high cost from carbon neutrality. The energy consumption cost from transportation is about Rmb3.9trn in 2021. The total cost of new energy would be about Rmb6.6trn, assuming all HDTs are powered by hydrogen, and MDTs, LDTs, PVs and trains all by clean electricity. As such, the zero carbon emission cost for the transportation industry is around Rmb2.7trn in 2021, implying a "green premium" of $68 \%$.

Overall, the road to carbon neutrality is costly and challenging for the transportation industry. For transportation, achieving carbon neutrality requires a combination of technological innovation and policy support. The next three sections will discuss the carbon emissions trend in the transportation industry, potential technological innovations, and public policy support.

\subsection{Viable Options for China to Achieve Green Transportation}

In previous sections we discussed carbon emissions from transportation in China, and analyzed difficulties for the industry to achieve carbon neutrality by calculating green premium. This section will mainly discuss the pathway of carbon emissions reduction. Carbon emissions of the transportation industry will be calculated, followed by the prediction of emissions from each transportation subsector. Specifically, transport turnover rate and ownership in the next 4 decades will be predicted, carbon emissions based on the forecasts will be calculated and assumptions on penetration of new energy and per-unit energy consumption will be made. Last but not least, specific options on decarbonization shall be provided.

\subsubsection{Carbon Emissions from the Transportation Industry: Emission Peak in 2030; Carbon Neutrality in 2060 Seems Unlikely Under a Neutral Assumption that Emissions in 2060 Equal 23\% of the Level in 2019}

\subsubsection{Transport Turnover in 2060 to Double the Level of 2019}

Turnover rate (i.e. tonnes-km) can measure carbon emissions more effectively than freight or passenger traffic volume. The transportation industry's turnover reached 
19.7trn tonnes-km in 2019, and may rise to 38.7 trn tonnes-km in 2060, implying a $1.7 \%$ CAGR in 4 decades. $^{4}$

We expect turnover growth in the next 4 decades to be $0.6 \%, 3.5 \%, 1.8 \%$ and $2.4 \%$ for road transport, aviation, marine transport and railway respectively (see Table 8.2). For road transport, expected turnover growth is the lowest as high-speed trains and airlines will divert passenger traffic and certain cargo owners may shift away from road transport to railway or waterway. In comparison, aviation sector is expected to

Table 8.2 Our forecasts for transport turnover in 2060

\begin{tabular}{l|l|l|l|l|l}
\hline $\begin{array}{l}\text { Transportation } \\
\text { turnover }\end{array}$ & 2019 & $2060 \mathrm{E}$ & $\begin{array}{l}2060 \mathrm{E} \\
\text { versus 2019 } \\
(\%)\end{array}$ & CAGR (\%) & Assumption \\
\hline $\begin{array}{l}\text { Total (bn } \\
\text { tonne-km) }\end{array}$ & 197,164 & 387,418 & 196 & 1.7 & \\
\hline
\end{tabular}

\begin{tabular}{|c|c|c|c|c|c|}
\hline \multicolumn{6}{|l|}{ By transport } \\
\hline Road transport & 60,425 & 78,408 & 130 & 0.6 & $\begin{array}{l}\text { We believe a portion } \\
\text { of highway } \\
\text { transportation will } \\
\text { continuously be taken } \\
\text { away by high-speed } \\
\text { rails and aviation; } \\
\text { compared to those } \\
\text { prior to } 2019 \text {, growth } \\
\text { rate of freight } \\
\text { transportation on } \\
\text { highways will slow } \\
\text { down driven by traffic } \\
\text { taken away by } \\
\text { railways }\end{array}$ \\
\hline Aviation & 1,293 & 5,393 & 417 & 3.5 & $\begin{array}{l}\text { Based on the case of } \\
\text { the US, CAGR of } \\
\text { aviation turnover is } \\
\text { around } 5 \% \text { if GDP per } \\
\text { capita is } \\
\text { US\$10,000-20,000; } \\
\text { CAGR of aviation } \\
\text { turnover is around 4\% } \\
\text { if GDP per capita is } \\
\text { US\$20,000-30,000; } \\
\text { CAGR of aviation } \\
\text { turnover is around } 2 \% \\
\text { if GDP per capita is } \\
\text { US\$30,000-40,000 }\end{array}$ \\
\hline
\end{tabular}

(continued)

\footnotetext{
${ }^{4}$ The Ministry of Transport's statistics on road passenger turnover do not include transportation by PVs. However, we take it into consideration when calculating carbon emissions.
} 
Table 8.2 (continued)

\begin{tabular}{|c|c|c|c|c|c|}
\hline $\begin{array}{l}\text { Transportation } \\
\text { turnover }\end{array}$ & 2019 & $2060 \mathrm{E}$ & $\begin{array}{l}2060 \mathrm{E} \\
\text { versus } 2019 \\
(\%)\end{array}$ & CAGR $(\%)$ & Assumption \\
\hline $\begin{array}{l}\text { Total (bn } \\
\text { tonne-km) }\end{array}$ & 197,164 & 387,418 & 196 & 1.7 & \\
\hline \multicolumn{6}{|l|}{ By transport } \\
\hline Shipping & 103,970 & 219,094 & 211 & 1.8 & $\begin{array}{l}\text { Driven by internal } \\
\text { circulation of the } \\
\text { economy, we believe } \\
\text { CAGR of } \\
\text { transportation } \\
\text { turnover of inland } \\
\text { rivers is } 3.4 \% \text {, which } \\
\text { is higher than that of } \\
\text { short seas }(2.0 \%) \text { and } \\
\text { that of deep seas } \\
(1.0 \%)\end{array}$ \\
\hline Railway & 31,476 & 84,523 & 269 & 2.4 & $\begin{array}{l}\text { We believe total } \\
\text { railway transportation } \\
\text { mileage will reach } \\
250,000 \mathrm{~km} \text { by } 2060 \text {, } \\
95,000 \mathrm{~km} \text { of which is } \\
\text { on high-speed rails. } \\
\text { Also by } 2060 \text {, the } \\
\text { density of China's } \\
\text { railway system will be } \\
\text { close to that of the US } \\
\text { railway system in } \\
\text { 2019; passenger } \\
\text { transportation will } \\
\text { benefit from the } \\
\text { increase of total } \\
\text { railway mileage; a } \\
\text { portion of freight } \\
\text { transportation through } \\
\text { highways will be } \\
\text { replaced by railways }\end{array}$ \\
\hline
\end{tabular}

Source Wind Info, CICC Research

record the highest turnover growth driven by rising per capita air trips and low-carbon railway and marine transport will also generate high turnover growth. 


\subsubsection{Under Our Neutral Assumption, We Expect Carbon Emissions from Transportation in 2060 to Plunge $77 \%$ from 2019}

The transportation industry emitted 1.16bn tonnes of carbon in 2019. Under our neutral assumption, we expect carbon emissions from transportation to peak at $1.33 \mathrm{bn}$ tonnes in 2030. The emission will plunge $77 \%$ from 2019 to $261 \mathrm{mn}$ tonnes in 2060 . Unless there are significant technology breakthroughs, we do not think the aviation and marine transportation sectors will achieve decarbonization by 2060 . As such, the transportation industry is unlikely to achieve carbon neutrality under neutral assumptions. However, technology advances may give positive shocks, and technological breakthroughs may help the transportation industry achieve carbon neutrality in the next 4 decades.

Overall, carbon emissions in the transportation industry will be affected by the increasing turnover rate, the improvement in fuel efficiency of each type of transport, and the replacement of traditional fossil fuels by low- or zero-carbon energy sources (e.g. applications of electric vehicles, LNG-powered vessels, and biomass jet fuel).

What are the assumptions timing (see Fig. 8.4 and Table 8.3).

The road transport (passenger) sector: Carbon emissions will peak in 2028 when ownership-based penetration rate of NEVs may reach around $10 \%$. The penetration rate of NEVs will rise continuously and reach $100 \%$ by 2045 , and all PVs will be NEVs thereafter, achieving carbon neutrality in 2060.

The road transport (freight) sector: Carbon emissions will peak in 2030 when ownership-based penetration rate of alternative-fuel trucks may reach around $10 \%$. In our view, the ownership-based penetration rate of electric MDT, LDT, and mini trucks will rise to $100 \%$ in 2050 , and the rate of fuel cell-powered HDTs will reach

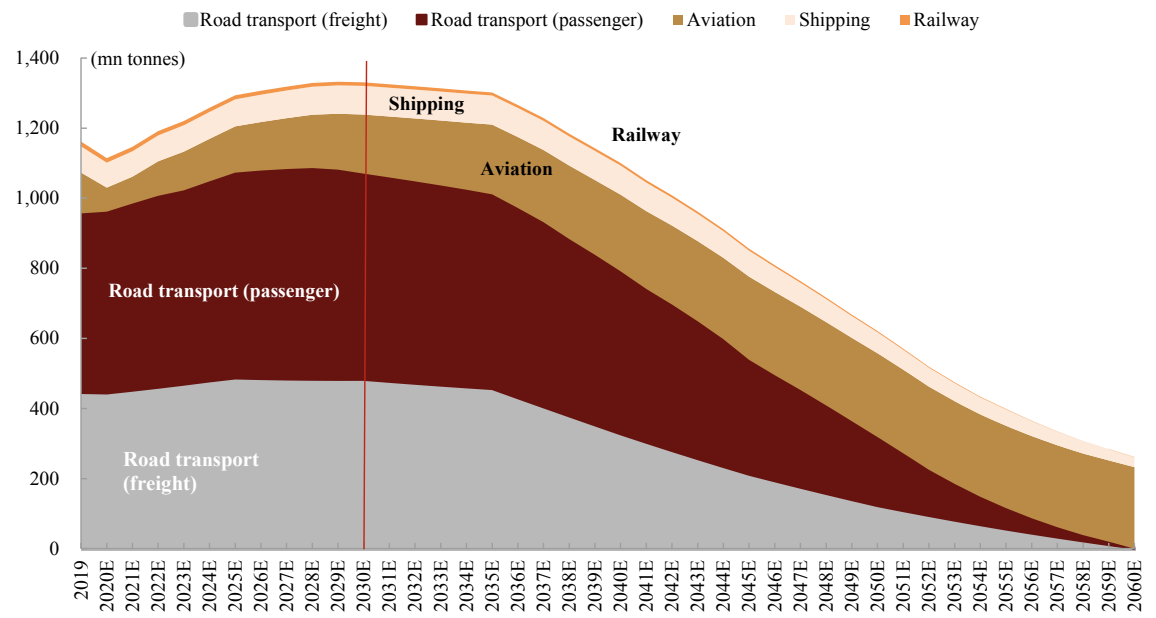

Fig. 8.4 Our forecasts for carbon emissions from transportation in 2020-2060. Note The red line indicates the timing that the transportation industry will reach peak carbon emissions. Source IEA, CICC Research 
Table 8.3 Major timing of carbon emissions from transportation sectors and our assumptions

\begin{tabular}{|c|c|c|c|c|c|c|c|}
\hline Tim eline & $2025 \mathrm{E}$ & $2028 \mathrm{E}$ & $2030 \mathrm{E}$ & $20 \mathrm{MOE}$ & 2045E & 2050E & $2060 \mathrm{E}$ \\
\hline $\begin{array}{l}\text { Key eventa related to } \\
\text { eufbon ematissions }\end{array}$ & & $\begin{array}{c}\text { Carbon peak for passenger } \\
\text { ears }\end{array}$ & $\begin{array}{c}\text { Carbon peak for } \\
\text { highwayn }\end{array}$ & $\begin{array}{c}\text { Carbon peak for } \\
\text { thippiag }\end{array}$ & & $\begin{array}{c}\text { Carbon peak for } \\
\text { aviation }\end{array}$ & $\begin{array}{l}\text { Carbon neutrality for } \\
\text { highwayn und railways }\end{array}$ \\
\hline $\begin{array}{l}\begin{array}{c}\text { Roud transport } \\
\text { (passenger) }\end{array} \\
\text { (a) }\end{array}$ & 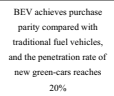 & 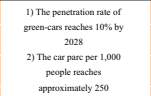 & & & 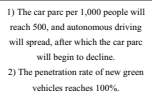 & & $10 \% \%$ green for passenger cars \\
\hline Road tran sport (fre ight) & 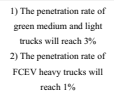 & & 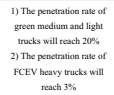 & 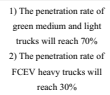 & & $\begin{array}{l}\text { The penetration rate of } \\
\text { green medium and } \\
\text { lighth rucks will raach } \\
100 \%\end{array}$ & $\begin{array}{l}\text { The penteration rate of grean } \\
\text { heavy trucks will reach 100\%\% }\end{array}$ \\
\hline Aviation & & & 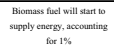 & $\begin{array}{l}\text { Hydrogen aitrcaf will } \\
\text { enter hle market }\end{array}$ & & $\begin{array}{c}\text { Biomass fuclel and } \\
\text { hydrogen will supply } \\
25 \% \text { of eneregy }\end{array}$ & $\begin{array}{l}\text { Biomaus fucl and hydrogen will } \\
\text { supply } 45 \% \text { of energy }\end{array}$ \\
\hline Shipping & $\begin{array}{l}\text { 1) Pencertation rate of } \\
\text { inland walet electric } \\
\text { vessels reaches } 1 \% \\
\text { 2) LNA replasec } 3 \% \text { of } \\
\text { Shipping fuel }\end{array}$ & & 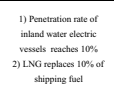 & & & & 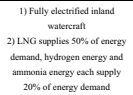 \\
\hline $\begin{array}{l}\text { Railway } \\
\text { 是 }\end{array}$ & $\begin{array}{l}\text { Railway electrification rate } \\
\text { reaches } 82 \%\end{array}$ & & $\begin{array}{l}\text { Ratilway electrification rate } \\
\text { reseches } 85 \%\end{array}$ & $\begin{array}{l}\text { Railway electrification } \\
\text { trale reaches } 91 \%\end{array}$ & $\begin{array}{l}\text { Railway electrififation rate reaches } \\
94 \%\end{array}$ & $\begin{array}{l}\text { Railtway electrification } \\
\text { trate reaches } 96 \%\end{array}$ & $\begin{array}{l}\text { Railway electrification rate } \\
\text { reaches } 1100 \%\end{array}$ \\
\hline
\end{tabular}

Source CICC Research

$100 \%$ in 2060 . In other words, we think the CV-based transport sector will reach carbon neutrality in 2060 .

The aviation sector: Emission peak will be reached in 2050. In our view, the penetration of biomass fuel and hydrogen energy in airplanes will rise to $25 \%$ in 2050 , and then rise gradually, but cannot completely replace traditional jet fuel. We expect the penetration of biomass fuel and hydrogen energy to rise to $30 \%$ and $15 \%$ in 2060, implying carbon emissions of $232 \mathrm{mn}$ tonnes, almost doubling the emissions in 2019 and accounting for $89 \%$ of total carbon emissions from transportation.

Marine transportation sector: Carbon emissions will peak in 2040. In our view, the penetration of new energy in this sector will reach $25 \%$ in 2040. Although LNG, hydrogen and ammonia will have an increasingly high penetration rate, traditional fuel cannot be completely replaced. Carbon emissions from marine transportation is expected to drop $62 \%$ from 2019 to about 29 mn tonnes in 2060 , accounting for $11 \%$ of total carbon emissions from the transportation industry.

Railway sector: Electrification adoption rate will rise to $100 \%$ in 2060 , helping the railway sector achieve carbon neutrality.

What may go beyond expectation or under expectation? Technology advances and applications of new energy are highly promising for the next 10-15 years. Yet the longer-term technological evolution is unpredictable.

Beyond expectation: (1) The era of intelligent driving is likely to arrive earlier than expected: When the era arrives, vehicle ownership may largely shrink and the PV-based transport sector may achieve carbon neutrality earlier than 2060; (2) fuel efficiency improvement might beat expectations: If carbon trading market matures, this may encourage companies to accelerate energy conservation and emissions reduction, leading to a positive fuel efficiency enhancement; and (3) technologies 
on hydrogen energy are likely to beat expectations, given recent breakthroughs in hydrogen storage technology. 5

Under expectation: (1) penetration rate of new energy in CV-based transport sector is slower than expected: As trucks are mostly owned by individuals that focus more on returns, we believe the penetration rate could be slower than expected before price parity is achieved; and (2) applications of biomass fuel in airplanes missing expectations: The applications require a sound biomass value chain, but collection and conversion of biomass raw materials are both challenging. As such, we believe the applications may miss expectations.

Optimistic and pessimistic scenarios on the transportation industry's carbon emissions roadmap are examined as follows (see Fig. 8.5): For the optimistic scenario, carbon emissions from transportation will peak in 2028 at $1.27 \mathrm{bn}$ tonnes (earlier than expected), and transportation will achieve zero carbon emissions in 2060. For the pessimistic scenario, we expect the emissions from transportation to peak at $1.44 \mathrm{bn}$ tonnes in 2035 and drop only 48\% from 2019 to 610mn tonnes in 2060.

In the next part, we focus on individual transportation sectors. We first discuss each sector's current emissions, predict future ownership, turnover and emissions in 2060, and then propose specific emissions-reduction options.

\subsubsection{The PV-Based Transport Sector: PV Ownership to Rise at First and then Decline; Zero Carbon Emissions to Be Achieved in 2060}

\subsubsection{PV Ownership to Rise First, then Decline, and Reach 531mn Units in 2060, Rising $158 \%$ from 2019}

China's PV ownership is expected to experience three periods:

Period I: From now to 2030. The Chinese economy will undergo mid- or highgrowth momentum and rising GDP per capita will lead to strong growth in PV ownership per 1,000 persons. China's PV ownership will expand from 210mn units in 2019 to $432 \mathrm{mn}$ units in 2030, in our view implying a $6.9 \%$ CAGR.

Period II: From 2030 to 2045. During the second period, the Chinese economy will reach a mature stage which GDP per capita will maintain at a mid- or low-growth momentum level, and growth of PV ownership per 1,000 persons will decelerate. China's PV ownership per 1,000 people in the longer term will be similar to levels in Japan and South Korea, and reach 500 units in 2045, still lower than the 800 units in the US. Chinese PV ownership will peak at 710mn in 2045, implying a 3.3\% CAGR.

Period III: From 2045 to 2060. In the third period, intelligent driving and traffic will effectively enhance transport efficiency, and hence reduce PV demand and drive

\footnotetext{
5 Balancing volumetric and gravimetric uptake in highly porous materials for clean energy, written by CHEN Zhijie Chen and LI Penghao, published in Science in April 17, 2020.
} 


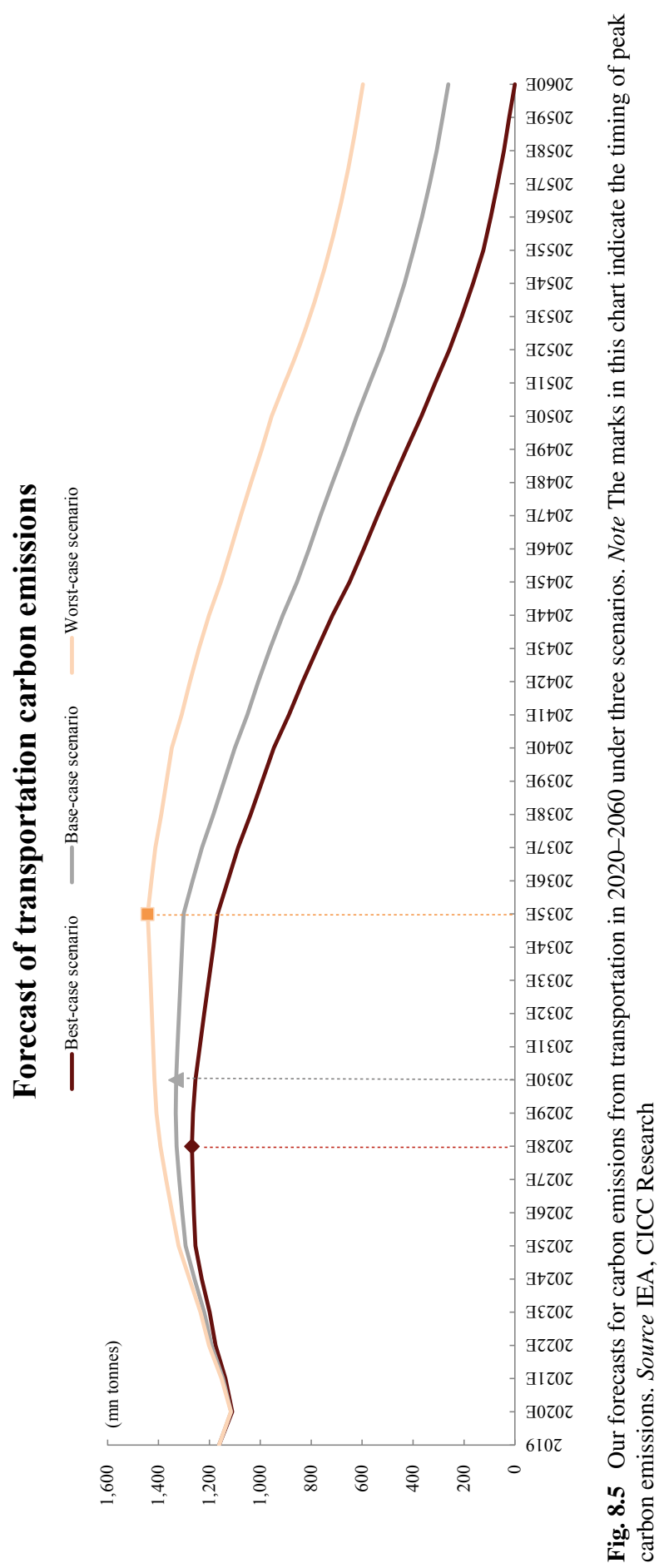


down PV ownership. Thus, China's PV ownership may drop to 531mn units in 2060, in our view implying a $-1.9 \%$ CAGR in 2045-2060.

\subsubsection{NEV Sales Volume Forecast: We Expect Alternative-Fuel PVs to Achieve a Purchase Price Parity in 2025 and Their Penetration Rate (Based on Sales) to Reach $100 \%$ in 2045}

Given the expected PV ownership, alternative fuel vehicle's penetration rate can be used as the most important factor when calculating carbon emissions. Installation cost of ternary battery packs in 2025 is likely to decline $35 \%$ from 2020 due to clear economies of scale and lower cost of LIB materials. This drop in cost should help pure electric vehicles achieve purchase price parity with traditional fuel vehicles, thus further driving up the penetration rate of pure electric vehicles. Alternative-fuel PVs had a penetration rate of $6.2 \%$ in 2020 (based on sales volume). Penetration rate is likely to reach $20 \%$ in $2025,50 \%$ in 2035 , and $100 \%$ in 2045 , given China's NEV industry blueprint for 2021-2035 and a technological roadmap for NEV and energy conservation.

We expect the PV-based transport sector to reach peak carbon emissions in 2028, given our forecasts for new energy vehicle penetration and energy conservation of traditional fuel vehicles. Based on our estimation, traditional fuel PVs will be all scrapped in 2060, and the PV-based transport sector will achieve zero carbon emissions.

\subsubsection{Energy Conservation and Emissions Reduction in the PV-Based Transport Sector Requires a Combination of Multiple Factors}

The technical pathways for the PV-based transport sector to acheive carbon neutrality mainly rely on energy conservation of traditional fuel vehicles and the use of clean energy. The next section will closely examine three different pathways: light materials, hybrid power, and LIB. The light material pathway is the least effective in emissions reduction, while the LIB option is the most effective.

The light material pathway can reduce the weight of a vehicle by $35 \%$ in 2030 compared with 2015. The light material pathway refers to the application of aluminum alloy, magnesium alloy and carbon fiber reinforced materials. According to a study made by European Automobile Manufacturers Association, a 100kg decline in a vehicle's weight can reduce oil consumption per $100 \mathrm{~km}$ and carbon emissions by $0.4 \mathrm{~L}$ and $1 \mathrm{~kg}$. We noticed that aluminum consumption per vehicle in the US and Europe increased steadily and both exceeded $180 \mathrm{~kg}$ in 2020 . In contrast, the amount in China was only $105 \mathrm{~kg}$ in 2017 , pointing to large upside. We expect the average vehicle weight in China in 2030 to decline $35 \%$ from 2015.

The hybrid power pathway is the best emissions-reduction option before NEVs completely replace traditional fuel vehicles. China Society of Automotive Engineers released a document on technological roadmap 2.0 for energy conservation 
and NEVs. According to this document, penetration rate of new hybrid vehicles may reach $50 \%$ in 2035 and hybrid vehicles could begin to completely replace traditional fuel vehicles. Hybrid vehicles are driven by both engines and electric motors, which can help engines work efficiently under different road conditions.

China's domestic automakers have developed hybrid power technologies. For example, SAIC Motor, Guangzhou Automobile Group, Great Wall Motor, Geely, and BYD have all released their hybrid power development platforms to better cope with increasingly tight oil consumption standard.

Mass LIB production is of great importance to carbon neutrality in the PVbased transport sector. NEVs still have significant disadvantages in comprehensive performance and driving experience. For example, their driving range declines considerably when the temperature is low, and hot weather tends to trigger thermal runaway in battery packs, raising strong consumer concerns on driving range and safety. LIB producers and automakers both play an important role in resolving such challenges.

LIB producers will settle technological constraints by optimizing battery material system and developing new cell technologies. We believe these efforts will quell consumer concerns on driving range to some extent and pave the way for NEVs to completely replace traditional fuel vehicles in $2045 .^{6}$

Emerging automakers began to work on vehicle intelligence, innovate business models, and improve driving experience. For example, Tesla has promoted fast charging technology, enlarging the maximum charging power to $250 \mathrm{~kW}$, which can meet consumer needs for charging time. In addition, we think rising penetration of smart electric vehicles will push consumers to shift away from traditional fuel vehicles to NEVs. Compared with its 1.0 platform, NIO's pilot 2.0 platform has significantly improved performance of smart electric vehicles in aspects such as algorithm, computing power, and hardware products.

\subsubsection{Carbon Emissions from CV-Based Transport Sector: Rising Applications of New Energy, Digitalization Technology and Changing Transport Structure to help this sector achieve carbon neutrality in 2060}

\subsubsection{Changing Freight Transport Structure to Reduce Demand for Road Freight Transportation}

After analyzing freight transport structure in the US and EU, we found that the structure is dominated by waterway in the EU and by railway in the US. These two regions have been less reliant on road transportation, whereas the exposure to road transportation is increasing in China.

\footnotetext{
${ }^{6}$ For detailed analysis, please refer to the technological section on green transportation.
} 
A number of government agencies began to promote switching freight transportation from roads to railways in 2017. The efforts paid off, as railway freight transport volume in 2019 increased about 1.06bn tonnes from 2016. The cost of road transport is twice that of railway transport and is four times that of marine transport. The per-unit energy consumption of road transport is 4 and 10 times that of railway and waterway transport. Furthermore, the shift in the demand for transportation service from roads to railways and marine will continue to divert freight sources and reduce the demand for road freight transport.

\subsubsection{CV Ownership: HDT Ownership to Peak in 2030; MDT and LDT to Reach Peak Ownership in $2045^{7}$}

HDTs: HDT ownership is expected to rise at first and then trend downward, and it will peak around 2030. Real estate, infrastructure construction, and road-based logistics will continue to boost HDT demand in the coming years. However, HDT demand is likely to decline in the longer term, as cargo owners shift away from road transport to railway and transport efficiency increases. HDT ownership is expected to peak at $10.40 \mathrm{mn}$ units in 2030 and drop to $8.17 \mathrm{mn}$ units in 2060 .

MDT, LDT and mini trucks: Ownership will peak in 2045. The ownership is affected by transport efficiency and road transport demand. According to our estimation, ownership of MDTs, LDTs and mini trucks will rise in the medium and long term driven by increasing urbanization rate, and then peak in 2045. Subsequently, the ownership of these subsectors will start to shrink as autonomous driving dominates the CV market. In addition, we think coach ownership has peaked and will remain stable in the long term.

\subsubsection{New Energy Vehicles Are Expected to Fully Replace Traditional Fuel Vehicles in 2060, Helping the CV-Based Transport Sector Achieve Carbon Neutrality}

The penetration rate will reach $100 \%$ in 2030 for alternative-fuel coaches, in 2050 for new-energy MDTs, LDTs and mini trucks, and in 2060 for alternative-energy HDTs. In other words, we think the CV-based transport sector will achieve carbon neutrality in 2060.

Alternative-fuel coaches will completely replace traditional coaches in 2030 as local governments buy a growing number of pure electric coaches.

The penetration rate of electric LDTs, MDTs and mini trucks will rise to $100 \%$ around 2050.

The rising penetration rate of fuel cell-powered HDTs depends on policy support and the magnitude of reduction in fuel cell cost. According to the technological

\footnotetext{
${ }^{7}$ HDT, MDT, and LDT refer to heavy duty truck, medium duty truck, and light duty truck, respectively.
} 
roadmap 2.0 on NEVs and energy conservation, the ownership of fuel cell-powered CVs may rise to around $1 \mathrm{mn}$ units in 2035, implying a penetration rate of about $8 \%$. As fuel cells generate electricity more efficiently and hydrogen storage technologies improve, hydrogen fuel cells will be widely used in HDTs, and fuel cell HDTs will fully replace traditional fuel HDTs in 2060.

The options on energy conservation and emissions reduction in the CV-based transport sector are listed as follows:

Option I: Hydrogen fuel cells replacing traditional fuel.

Using hydrogen fuel cells becomes an important option for the CV-based transport sector to save energy and reduce emissions because of their extensive raw material sources and they are also more environmentally friendly. Hydrogen fuel cells have a definite technological direction, but the development of such technologies is still in its infancy. More details are provided in the next section.

Option II: A combination of power unit technology and exhaust gas after treatment technology.

In the past decade, China has repeatedly upgraded its emissions standard on internal combustion engines, and each upgrade is associated with the release of stricter emissions requirements. For example, under the China VI emissions standard for HDTs (effective in July 2021), the emissions cap on hydrocarbon and carbon monoxide is only half the level under the China V standard, and the limit on particulate matters is $1 / 10$ of the specified number in the previous standard. China will continue to upgrade the emissions standard and launch China VII standard in the next decade which may have stricter requirements for pollutant emissions.

Option III: Digitalization enhances road freight transport efficiency.

Digitalization technology can effectively eliminate agents and settle the problem of freight-truck matching. Specifically, freight-truck matching platforms can reduce the time that truck drivers spend in finding loads and raise matching efficiency by leveraging big data and algorithms based on drivers' locations, habits and routes. According to a report from Sohu, ${ }^{8}$ monthly average driving mileage facilitated by Fuyou (a truck-freight matching platform) is $22 \%-57 \%$ higher than the level under traditional dispatching model. Based on transportation data in 2019, we estimate that a $1 \%$ decline in the proportion of deadhead trucks can reduce carbon dioxide emissions by about 7.30mn tonnes, accounting for $1.6 \%$ of emissions from the CVbased transport sector in 2019.

${ }^{8}$ https://www.sohu.com/a/354965965_168370 (source in Chinese). 


\subsubsection{The Aviation Sector: Emissions in 2060 to Double from 2019; Achieving Carbon Neutrality is the Most Challenging for All Modes of Transport}

This section will first discuss current emissions from the aviation sector, then estimate its turnover rate and emissions in 2060, followed by predicting the emissionsreduction options such as the use of alternative fuel, operation optimization and carbon offsetting and reduction scheme.

\subsubsection{In the Past Decade, Aviation Turnover Drove High Growth in Carbon Emissions}

The aviation sector emitted $117 \mathrm{mn}$ tonnes of carbon in 2019 (including international flights), accounting for about $10 \%$ of emissions from the transportation industry and implying an $11.5 \%$ CAGR in the past decade driven mainly by aviation turnover expansion (an $11.7 \%$ CAGR in the past decade).

\subsubsection{The Aviation Sector is Unlikely to Completely Achieve Decarbonization; Its Carbon Emissions to Double in 2060 Under Neutral Assumptions}

There is rising demand for air passenger and freight transportation. In 2019, China's per capita air trips was only 0.4, much lower than levels of 2.2 in the EU and 2.8 in the US. Air passenger and freight traffic in 2060 are expected to be 3.7 and 3.2 times the respective levels in 2019.

In our view, the aviation sector is unlikely to achieve decarbonization completely, and jet fuel replacement by new energy and operation optimization are two options for emissions reduction in this sector. The aviation sector is characterized by heavy energy consumption and long transport distances, posing strong challenges to decarbonization. As such, energy conservation and emissions reduction are of vital importance.

The aviation sector is estimated to emit about $232 \mathrm{mn}$ tonnes of carbon in 2060, doubling the emissions in 2019. Assumptions for the above conclusion are as follows: (1) penetration of biomass fuel to rise to $30 \%$ in 2060; (2) hydrogen-powered planes to be commercialized in 2040 and have a penetration rate of $15 \%$ in 2060; and (3) per-unit fuel consumption efficiency rising $0.5 \%$ per annum.

What are the areas that may exceed and fall short of expectations? The part that exceeds expectations: Technological advances tend to exceed expectations, so there is a possibility that hydrogen aircraft will have unprecedented breakthrough. Lower than expected: We believe that the development of biomass fuel oil may be lower than expected, mainly because the collection, transportation and conversion of biomass fuel is difficult to scale. 
Forecast of carbon emissions of the aviation transportation segement

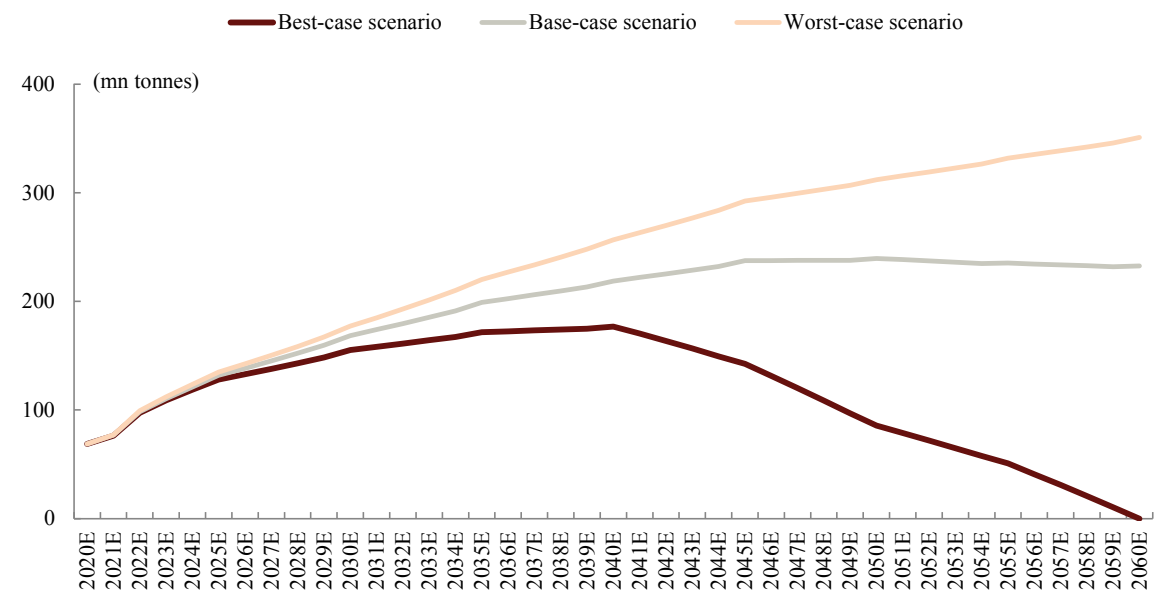

Fig. 8.6 Our scenario analysis and assumptions on carbon emissions from the aviation sector in 2020-2060. Source CICC Research

Overall, we expect the aviation sector to achieve carbon neutrality in 2060 under our optimistic scenario. This sector will emit about $351 \mathrm{mn}$ tonnes of carbon in 2060 under our pessimistic scenario, tripling the emissions in 2019 (Fig. 8.6).

\subsubsection{Option 1: Alternative Energy Replacing Traditional Jet Fuel}

The alternative energy that is most suitable for airplanes includes biomass fuel, hydrogen energy, and electrical energy. We are relatively upbeat on the applications of biomass fuel after comparing these three energy sources.

The biomass fuel technology is more mature than technologies on hydrogen and electrical energy. China and other countries have produced biomass fuel and applied it to airplanes. For example, the bio-jet fuel made by Sinopec was successfully used in China Eastern Airlines' planes as early as 2013. Moreover, biomass fuel being mixed with existing jet fuel and then used in existing plane engines has been proven feasible.

The application of hydrogen fuel in planes could reshape aircraft architecture. With flying distance being unchanged, the space needed for storing hydrogen fuel is 4-8 times the storage space for traditional fuel. As such, we believe the structure of hydrogen-powered aircraft is very likely to be revamped. Completing the processes of designing, testing and verifying new aircraft normally takes 10-20 years. Therefore, we do not think hydrogen-powered aircraft will be commercialized in the near term. 
The weight of batteries may equal or remain lower than maximum take-off weight only when their energy density rises 6-8 times, which is technologically challenging. Thus, pure electric aircraft can only meet requirements for short distance flying.

How much can new energy meet energy demand from aircraft in 2060 ?

Under neutral assumptions, biomass fuel can meet $30 \%$ of energy demand from aircraft. Energy Transitions Commission and Rocky Mountain Institute estimate in a report that China's biomass energy supply potential could be 400-850mn tonnes of standard coal. Given the difficulties in building the biomass value chain, we conservatively assume the potential is $400 \mathrm{mn}$ tonnes. Excluding the biomass energy for power generation, chemical material production, and heating for buildings, 40mn tonnes of standard coal (i.e. $10 \%$ of the assumed potential) will be used to power aircraft in 2060 under neutral assumptions, accounting for about $30 \%$ of jet fuel demand in the same year.

Hydrogen fuel can meet $15 \%$ of energy demand from aircraft under the neutral assumption. Hydrogen-powered aircraft are unlikely to be commercialized until 2040 after technological breakthroughs are made. As such, hydrogen fuel can meet $15 \%$ of energy demand from aircraft under the neutral assumptions.

We cannot rule out the possibility that other new energy sources (e.g. nuclear energy and solar kerosene) can be used as jet fuel. However, delevopment of relevant technology is still in the early stages. In our view, before new energy replaces traditional jet fuel, improving operations to save fuel consumption ${ }^{9}$ is also of great importance to emissions reduction in the aviation sector.

\subsubsection{Option 2: Improving Operations Can Moderately Reduce Carbon Emissions}

Improving operations mainly includes optimization in the flying process, routes and aircraft fleets.

Optimization of flying process: A study made by EUROCONTROL shows that persistent ascending and descending can help aircraft reduce carbon emissions by about $0.6 \%$.

Shortening flying distance: In our view, relying on radar to guide non-stop flights and opening temporary routes can shorten flying distances. For example, China Eastern Airlines' Shanghai-London flight reduced flying distance by $270 \mathrm{~km}$ by taking similar measures. ${ }^{10}$

In addition to these optimization measures, improving aircraft design and engine thermal efficiency can also reduce carbon emissions. However, China benefits from the potential improvement mainly because it is a buyer of aircraft (the research and development of commercial aircraft might help improve the energy efficiency

\footnotetext{
${ }^{9} \mathrm{We}$ assume $0.5 \%$ of jet fuel is saved per year.

${ }^{10} \mathrm{http}: / /$ www.caacnews.com.cn/1/6/201803/t20180312_1242843.html (source in Chinese).
} 
of domestically-made aircraft). Overall, operation optimization can reduce carbon emissions moderately per annum.

Are there any other options if the abovementioned options cannot help the aviation sector completely achieve decarbonization?

\subsubsection{CORSIA Can Help International Air Transportation Market Achieve Net Zero Carbon Emissions}

What is CORSIA?

CORSIA (Carbon Offsetting and Reduction Scheme for International Aviation) is a carbon-reduction system that is launched by International Civil Aviation Organization (ICAO) to cover international flights. Under CORSIA, which starts in 2021, airlines buy carbon offset credits to cover any emissions from international flights above the current baseline of average emissions in 2019 so as to achieve zero emissions compared to 2019 level.

China has not participated in CORSIA so far. Its aviation industry may face mounting cost pressure if the country becomes a member. However, this may also help the industry strive to enhance efficiency and reduce cost. We estimate, based on our previous assumptions on turnover and penetration of new energy, that carbon offsetting cost of international flights should be around Rmb8.4-16.8bn in 2060 (assuming carbon price of EUR20-40/tonne). If the cost is passed on to consumers, we estimate this would boost the round-trip ticket of the $4,000 \mathrm{~km}$ flight between Shanghai and Singapore by $2 \%-4 \%$. From our point of view, CORSIA may spur the Chinese aviation industry to speed up energy conservation and emissions reduction, amid the high offsetting cost.

\subsubsection{Marine Transportation: Carbon Emissions in 2060 to Be 38\% of the Emissions in 2019}

\subsubsection{Marine Transportation Accounts for Only a Small Proportion of Total Emissions from the Transportation Industry; Its Emission Growth Remains Slow, and Per-Unit Energy Consumption Has Dropped Rapidly}

We estimate marine transportation (including international routes) emitted $74.70 \mathrm{mn}$ tonnes of carbon in 2019, accounting for $5.4 \%$ of total carbon emissions from the transportation industry and implying a 1.4\% CAGR in the past decade. We attribute the slow CAGR to rapid decline in per-unit energy consumption ( $-31 \%$ in 2019 from 2009). 


\subsubsection{Carbon Emissions from Marine Transportation in 2060 to Drop 62\% from 2019 Under Neutral Assumptions}

We expect marine transportation turnover growth to stay low all the way to 2060 (1.8\% CAGR). Replacing traditional fuel with new energy and helping vessels raise energy efficiency are two emissions-reduction options.

The carbon emissions of the marine transportation sector are estimated to contract $62 \%$ from 2019 to about $29 \mathrm{mn}$ tonnes in 2060. Our assumptions include: (1) all vessels sailing on domestic waterways to be powered by electricity in 2060; (2) ships along coastlines and ocean-going vessels to be powered by diversified energy sources ( $50 \%$ by LNG, $20 \%$ by ammonia and $20 \%$ by hydrogen energy); and (3) perunit fuel consumption to fall by an average of $1 \%$ per year. The marine transportation sector can achieve carbon neutrality in 2060 under the optimistic scenario, and its carbon emissions in 2060 will drop $20 \%$ from 2019 under the pessimistic scenario.

\subsubsection{Option 1: Clean Energy Replacing Traditional Fuel}

Clean energy sources for marine transportation mainly include electricity, ammonia, hydrogen and LNG. We are upbeat on the use of electric ships in domestic waterway transportation. On domestic waterways, transport distance is shorter (about $400 \mathrm{~km}$ ), and ships have lower deadweight tonnage (around 1,500tonnes), laying a technological foundation for using electricity- or fuel cell-powered ships. For coastal and ocean sailing, the technology on LNG-powered vessels is relatively mature, but that of ammonia- or hydrogen-powered ships has not matured.

The technology on LNG-powered vessels is relatively mature. LNG is sulfur free, and emits $20 \%$ less carbon than traditional fuel. IMO's $0.5 \%$ global sulfur cap on marine fuel may push the marine transportation industry to use LNG.

The use of ammonia and hydrogen as clean energy still needs further advancements in technology. Ammonia has been widely used to produce fertilizer, but its use as clean energy has not matured. For example, the use of ammonia relies on engine renovation and a specific energy supply system. The applications of hydrogen energy, to a large extent, require solutions to a number of issues on hydrogen size, density and engines.

In addition, other new energy sources such as methanol may also be used to replace traditional marine fuel.

\subsubsection{Option 2: Improving Energy Efficiency for Vessels}

For energy efficiency, new vessels need to meet requirements from EEDI (Energy Efficiency Design Index), while existing carriers need to comply with SEEMP (Ship Energy Efficiency Management Plan). CE Delf and UMAS estimate that improvement in energy efficiency can help vessels reduce carbon dioxide emissions by up to $8 \%$. 


\subsubsection{Railway Transport: Zero Carbon Emissions in 2060 Via Electrification-Based Decarbonization}

\subsubsection{Carbon Emissions from Railway Transportation Contracted in the Past Decade Thanks to Higher Electrification Rate}

Railway transportation is estimated to have emitted $13.84 \mathrm{mn}$ tonnes of carbon in 2019, plunging 50\% from 2009 and implying a CAGR of $-7.2 \%$ in the past decade. Electrification rate in the railway sector expanded 36ppt in the last 10 years, which is a major driver for the plunge in emissions.

\subsubsection{The Railway Transport Sector Relies on Electrification to Achieve Decarbonization}

China's railway operating length totaled $140,000 \mathrm{~km}$ as of 2019 , with $40,000 \mathrm{~km}$ of railways have not been electrified. The country built about $5,500 \mathrm{~km}$ of rail lines per annum in the past decade, and these lines are mostly electrified. In addition, an extra $1,050 \mathrm{~km}$ of old lines went under electrification transformation per year in the last decade. Under a neutral assumption that an extra $1,000 \mathrm{~km}$ of existing lines become electrified each year in the future, the electrification rate will rise to $100 \%$ in 2060. In other words, the railway transport sector may achieve zero carbon emissions in 2060. The cost of railway electrification renovation is Rmb4-6mn/km, indicating renovating $1,000 \mathrm{~km}$ of railway per year would cost around Rmb4-6bn, accounting for only 4-6\% of China State Railway Group's funds available for use. China's railway sector is very likely to achieve full electrification.

Overall, a full range of options that China has on the road to green transportation has been provided. The most important option is the use of new energy. The use of electrical energy (automotive batteries) and hydrogen energy (fuel cells) is essential to emissions reduction in the road and air transportation sectors. The technological roadmaps based on these two options will be discussed in the next section.

\subsection{Forecasts for the Use of LIB and Hydrogen Fuel Cell Technologies}

As mentioned above, electricity, hydrogen and other new energy sources are crucial to China's initiative of hitting peak carbon emissions by 2030. In the section discussing "green premium", we mentioned that policies and technologies are two major factors that can propel carbon emissions reduction. This section will focus on technologies, especially lithium-ion battery (LIB) technologies and hydrogen fuel cell technologies. 


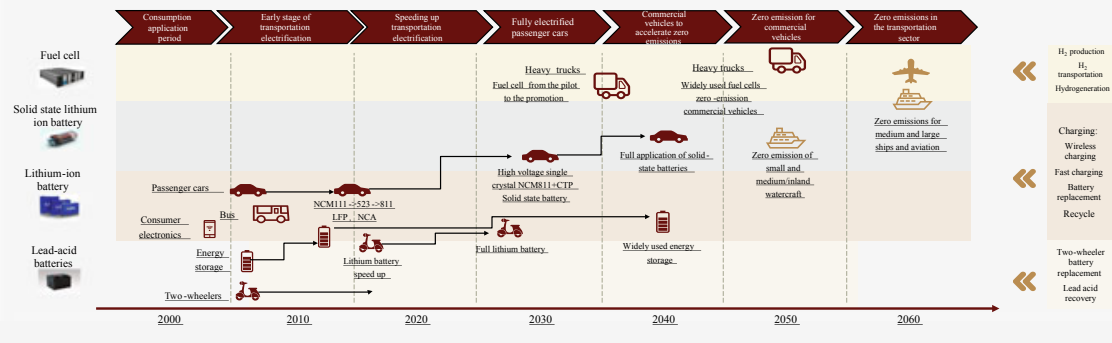

Fig. 8.7 Technologies used in the transportation industry. Source GGII, CICC Research

LIB: As an energy carrier for electric vehicles, LIBs are being used widely across the world. Electric PVs with a driving range of $600-800 \mathrm{~km}$ will achieve price parity over 2021-2025, thanks to lower costs and better quality enabled by advanced battery technologies. New-generation technologies (such as solid-state batteries) are expected to emerge over 2025-2030. The industrialization of these technologies will promote electrification in a growing number of areas such as ships and small aircraft over 2030-2040. Coupled with carbon footprint monitoring in manufacturing and recycling industries, this trend indicates that the industries that utilize LIB are likely to achieve zero-carbon emissions.

Hydrogen fuel cells: Medium- and long-term clean energy solutions to emissions from HDT-based transportation. Due to the characteristics of its cost, the fuel cell system is more likely than LIBs to be used for medium- and long-haul transportation by HDTs. The cost and performance of the hydrogen fuel cell system will meet the commercialization requirements over 2030-2040, and that alternative fuel-enabled electricity generation projects will propel the use and price parity of hydrogen energy. HDT-based transportation will achieve zero-carbon emissions over 2040-2060, given potential commercialization of hydrogen fuel cell systems and hydrogen fuel cell-powered HDTs amid price parity.

The application trend of technologies used in the transportation industry is shown in Fig. 8.7.

\subsubsection{LIB to Promote Electrification in PV-Based Transport and Certain Public Transportation Sectors}

As mentioned earlier, zero carbon emissions in the PV-based transport sector relies on the eventual adoption of pure electric vehicles. Penetration rate of NEVs (based on sales volume) is likely to reach $100 \%$ in 2045 , which to a large extent depends on the performance and technological roadmap of LIB technologies. 
On the demand side, the incremental installation of electric vehicle (EV) batteries in PVs will peak in China in 2045. Installations will increase at a CAGR of $21 \%$ over 2020-2045 and reach 4,140GWh in 2045 (vs. 36GWh in 2020).

There is high visibility regarding the evolution of EV battery technologies and the resulting price parity. In our view, lithium iron phosphate (LFP) batteries will first help NEVs with low- or mid-driving range to achieve price parity with traditional fuel vehicles, and then nickel-rich ternary batteries will follow suit, boosting the market demand. We foresee the commercialization of solid electrolyte batteries, lithiumsulfur batteries, lithium-air batteries, and other next-generation batteries over 20302060. We think these trends will further improve the performance of LIB, and enable electrification in additional industries.

Price parity to be partially achieved in the short term (2021-2023): NEVs with selling prices at Rmb100,000-150,000/unit and a driving range of less than $450 \mathrm{~km}$ will achieve price parity over 2021-2022, thanks to the use of LFP batteries.

Price parity to accelerate electrification in the medium term (2023-2030): As LIB technologies advance and industrialization capability improves, the use of nickel-rich cathode LIBs will accelerate, further reducing their cost and raising their quality. We expect EVs with a driving range of around $600 \mathrm{~km}$ and more than $800 \mathrm{~km}$ to reach price parity with fossil-fuel vehicles over 2024-2025 and 2026-2030.

Next-generation technologies to be used in the long term (after 2030): We believe commercialization of next-generation batteries (such as solid-state batteries, lithium-sulphury batteries, and lithium-air batteries) will propel the evolution of advanced battery technologies. These technologies will improve battery safety and enhance battery energy density, thereby increasing the use of NEVs that are more advanced and have a range of more than $1,000 \mathrm{~km}$. They will also likely be used in other areas such as small aircraft.

\subsubsection{Hydrogen Fuel Cells to Enable Zero-Carbon Emissions from HDT-Based Transportation}

Fuel cells are a chemical device that converts the chemical energy contained in fuel into electric energy. According to fuel types, they can be categorized into hydrogen fuel cells as well as methane, methyl alcohol, and ethanol fuel cells. Hydrogen fuel cells are more likely to be commercialized, thanks to multiple advantages (such as safety and clean by-products). Hydrogen energy's volumetric energy density is on par with that of LIB, but it outperforms LIB in terms of mass energy density. As such, hydrogen energy is more likely to be used in long-haul HDTs.

The system cost of hydrogen fuel cells and the cost of using hydrogen energy are both high at the moment. In 2019, the system cost of fuel cells averaged $\mathrm{Rmb} 20,000 / \mathrm{kW}$ in China. We estimate that fuel cell systems will reach price parity with HDT engines after the system cost drops to Rmb300-500/kW. 
China is also likely to build a domestic value chain in 2020-2025. The country's hydrogen fuel cell industry now relies heavily on overseas materials. Given government subsidies and domestic demand, we believe China can produce its core materials by 2025 . The system cost of hydrogen fuel cells is estimated to drop $90 \%$ from $\mathrm{Rmb} 20,000 / \mathrm{kW}$ in 2019 to $\mathrm{Rmb} 2,000 / \mathrm{kW}$ in 2025 , thanks to domestic production and the use of advanced technologies from other countries.

Fuel cell system will achieve price parity over 2025-2040 amid further expansion of domestic value chain, major materials advancement and economies of scale. Domestic value chain will expand further and comprehensive system technologies are likely to improve by 2035 , thereby helping reduce the system cost to Rmb300500/kW (down around 70\%-80\% from 2025). The fuel cell system will reach price parity with traditional HDT engines by 2035.

The costs of manufacturing, transporting, and refilling hydrogen accounts for $25 \%, 19 \%$ and $56 \%$ of the total cost of hydrogen consumption in the end market. We expect hydrogen energy to reach price parity driven by diesel with cost reduction in the aforementioned areas.

The two main methods for generating hydrogen include the natural gas and coal gas reforming method and the alternative fuel-based electricity generation method. However, a growing number of companies are trying to generate hydrogen via the alternative fuel-based water electrolysis method in the medium and long term. The cost of hydrogen generation via the reforming method and carbon capture technologies has fallen short of Rmb20/kg in energy-rich regions.

In contrast, amid the current electricity prices, the cost of hydrogen generation via the water electrolysis method is high at more than Rmb40/kg. However, the cost of such hydrogen will drop to less than 10/kg after 2025, as: (1) alternative fuel-based electricity generation accounts for a rising proportion of total electricity generation; and (2) alternative fuel-based electricity prices will likely be low at Rmb0.1-0.3/kWh in energy-rich regions. The cost of such hydrogen will likely drop to around $\mathrm{Rmb} 5 / \mathrm{kg}$ after 2040. In addition, economies of scale will produce notable impacts on costs. As such, centralized and large-scale hydrogen generation will play a major role in cost reduction in the medium and long term.

The decline in transport cost depends on technological advances and expansion of application scale. High-pressure hydrogen is mostly transported in Type-III cylinders in China, while it is mostly transported in Type-IV cylinders overseas. ${ }^{11}$ The transport cost in 2030 will drop 30\%-50\% from current levels, thanks to advanced technologies and expansion of application scale in China.

Hydrogen refilling costs are expected to drop markedly with domestic production of key equipment and accelerating construction of hydrogen stations. The cost of building a 35Mpa hydrogen station is high at US\$2-2.5mn in China, as: (1) key equipment is being mostly imported from other countries; and (2) depreciation and maintenance account for a high proportion of total hydrogen station cost. The cost of refilling hydrogen will drop rapidly driven by accelerating construction of hydrogen

\footnotetext{
${ }^{11}$ Type-IV cylinders can contain more hydrogen than Type-III cylinders, and the manufacturing techniques for Type-IV cylinders are more complex.
} 
stations and domestic production of key equipment hydrogen refilling cost will fall short of Rmb10/kg after 2030 (vs. nearly Rmb40/kg at present).

\subsection{Supportive Policies to Help the Transportation Sector Achieve Carbon Neutrality}

In the previous two sections, we elaborate on the feasibility and ways to achieve carbon neutrality in the transportation industry. In this section, we discuss how to leverage supportive policies to reduce carbon emissions from transportation, and give our policy suggestions from the perspective of industrial development and technological advances.

\subsubsection{Policy Suggestions on Industrial Development-PV and CV: Shifting the Focus of Policies Towards Market Orientation and Innovation}

\subsubsection{Domestic Policies on NEVs: Marginal Effect from Subsidies Weakening; "Dual Credit” Policy to Guide Long-Term Industry Development}

China's government and governments around the world mainly promote the development of the NEV industry through short-term subsidies and long-term guidance. As subsidies are gradually scrapped in China, the marginal effect from subsidies will weaken, and the "dual credit" policy, as a substitute for subsidy policy, will guide the long-term industry development, in our view. In the EU, automakers that fail to meet the carbon emissions target may face substantial fines, pushing them to shift away from fossil-fuel vehicles to NEVs. In the long term, carbon emission assessment will guarantee the healthy development of the industry following the subsidy cut.

\subsubsection{Guiding Technological Roadmap to Enhance Overall Quality of NEVs}

With subsidies gradually being scrapped, high-quality NEV models will become more important in boosting NEV penetration rate. Therefore, the policy focus should be encouraging automakers to produce more high-quality NEV models.

Guiding technological roadmap: The "dual credit" policy promotes the use of hybrid power technology in fossil fuel vehicles, and requires automakers to further raise the proportion of all-electric vehicles. To accumulate credits, certain vehicle manufacturers produce low-quality NEVs, and sell them to taxi companies at a low 
price which weighs on NEV demand from individuals. We believe the criteria for granting credits can be further specified. For example, indicators such as driving range, battery safety, and energy conversion efficiency could be considered to encourage the production of higher-quality NEVs.

Vehicle-related taxation: Allowing local governments to collect part of the vehiclerelated tax revenue can stimulate cooperation between local governments and local automakers. Taxation policies should encourage both purchases and the use of NEVs.

\subsubsection{Encouraging Innovation to Remove Hindrances to NEV Sector Development}

LIB technology is not yet mature. Policies should be directed at removing customer pain points in NEV purchases and promoting the development of NEV infrastructure.

The focus of subsidies should gradually shift from NEV purchases to the development of NEV infrastructure. In particular, subsidies are necessary to fund the construction of infrastructure facilities such as EV charging spots and EV battery swapping stations, so as to enhance the convenience of driving NEVs.

Policymakers should support business model innovation. For example, selling NEVs and batteries separately can reduce the initial vehicle purchasing cost, and quell consumer concerns on battery life. However, China needs to launch new policies to clearly define the ownership of NEVs and batteries. In addition, EV battery swapping stations are mainly operated under an asset-heavy model, and require heavy investment in the early stages. These stations are unlikely to achieve largescale commercialization unless they receive government subsidies and capital market support.

\subsubsection{Reduction of Carbon Emissions from Vehicles on the Road}

Forming more environmentally friendly driving habits: Improper driving behavior such as street racing and poor driving habits such as random lane changes cause extra gasoline consumption as well as additional carbon emissions. Therefore, applying driver-monitoring technology will better discipline drivers, and further reduce carbon emissions from vehicles.

Internet-connected vehicles to reduce traffic jams: Vehicles that are connected to the internet can choose the best route based on cloud data, enhancing transportation efficiency. Thus, the installation of roadside sensors and signal reception devices will effectively promote internet-connected vehicles, thereby reducing carbon emissions. 


\subsubsection{Policy Suggestions on Industry Development-Airlines: Focusing on Development of Biomass and Hydrogen Energy}

\subsubsection{Alternative Energy Sources: Offering Subsidies for Mature Biomass Fuels; Paying Attention to the Development of Hydrogen Energy}

We believe the government can offer subsides to create the aviation biomass fuel market. Biomass fuels for aircraft are expensive, which is a major restraint on market demand and economies of scale. We thus believe regulators should offer subsidies to fill the price gap between biomass fuels and traditional fuels to promote the development of the biomass-fuel value chain.

We believe the government should promote the combination of other new energy sources such as hydrogen with aeroengines. China still lags other countries in aircraft manufacturing technology, and we suggest paying attention to hydrogen-enabled technological advances.

\subsubsection{Policy Suggestions on Technological Advances-LIB: Zero Emissions Throughout the Lifecycle Requires Coordination Between Companies and Governments}

Carbon emissions from LIBs should be evaluated throughout the full lifecycle. While driving cars powered by LIBs is carbon emission-free, the manufacture of LIBs and treatment of used LIBs both produce carbon emissions.

China needs to further improve policies to push the automotive battery value chain to achieve zero carbon emissions. A number of authorities have released a series of policy moves to strengthen recycling of unused NEV batteries. However, they have not clarified the details. In addition, China also needs to issue clear policies to push NEV producers to save energy and reduce carbon emissions. We suggest policymakers take the following actions:

Establishing a system of traceability management during the battery lifecycle to track carbon footprints in each step: The Ministry of Industry and Information Technology (MIIT) has built a comprehensive management platform for national NEV monitoring and automotive battery recycling. Authorities also need to promote carbon footprint traceability in each step of the value chain, and ensure effective implementation of a system that incorporates rewards and punishments, in order to push the value chain to control and reduce carbon emissions.

Clarifying the parties liable for automotive battery recycling, and building a recycling network that consists of $4 \mathrm{~S}$ stores, NEV producers and third-party institutions: The Ministry of Industry and Information Technology (MIIT) has clearly stated that NEV producers are held liable for recycling automotive batteries. Thus, China needs 
to further improve the recycling network, clarify the details on storage, logistics and reprocessing, and explore viable business models and interest-distribution options.

Relying on mandatory policies and a system that incorporates both carrots and sticks to guide alternative fuel vehicle makers and users to actively participate in automotive battery recycling: China has built a system of LIB traceability and recycling, but compliant channels have not played an important role in the recycling. The government should set up a clear system that incorporates rewards and punishments, clarify regulatory options, and make NEV makers more interested in recycling. In addition, China also needs to strengthen the automotive battery traceability system, and rely on rewards or subsidies to guide users to participate in recycling.

\subsubsection{Policy Recommendations-Fuel Cells: It is Necessary to Promote Industrialized Applications of Fuel Cells Via Policies}

The adoption of hydrogen fuel cells is still at a very early stage. Chinese suppliers of hydrogen fuel cells lag their foreign counterparts in terms of both expertise and scale. In addition, the adoption of hydrogen fuel cells requires substantial infrastructure investment, and the hydrogen fuel cell industry cannot offer decent returns in a long time if there are no supportive policies. In other words, R\&D, production, adoption, and infrastructure construction all need policy support.

Current policies: China launched a 4-year campaign of pilot promotions of hydrogen fuel cell-powered vehicles in September 2020. In the period of the pilot promotions, the country aims to build a full value chain, focus on technological innovations, target applications in actual scenarios and explore effective business models to support healthy development.

Our longer-term policy recommendations: Given FCH-JU's report Hydrogen Roadmap Europe: A sustainable pathway for the European Energy Transition, the adoption of hydrogen fuel cells needs the following supportive policies in the long term:

First, policymakers should promote construction of hydrogen energy infrastructure and formulation of fuel cell standards, and clarify liabilities of each party in the value chain. The hydrogen fuel cell industry now lacks regulatory standards, especially on the infrastructure side. Formulating standards can facilitate construction and investment of hydrogen fueling stations, and accelerate infrastructure construction. In addition, the hydrogen fuel cell system also needs to further improve technological, production and qualification standards to promote mass adoption.

Second, China needs to formulate a long-term infrastructure construction plan to ensure large-scale adoption and visible development in the medium and long term.

The country also needs to further clarify and guide adoption roadmaps for hydrogen energy in specific transport scenarios, and make clear promotion targets. 
China should promote cross-border cooperation on the adoption of hydrogen fuel cell systems, expand its coverage of the global value chain, and accelerate industrial expansion.

\subsection{Reassessing the Effectiveness of Our Green Transportation Solutions Based on the "Green Premium"}

In previous sections, we predicted the trend of carbon emissions from transportation by 2060, and discussed green transportation solutions including technological roadmaps and necessary policies. In this section, we measure the effects of these solutions again from the perspective of "green premium".

\subsubsection{The "Green Premium" to Decline Considerably, but Unlikely to Plunge to Zero in 2060}

As estimated in the previous section, the "green premium" for the transportation industry is $68 \%$ in 2021, implying a zero carbon-emissions cost of Rmb2.7trn. This indicates decarbonization in this industry would be costly and challenging. Given our forecast carbon-emissions trends, we intend to calculate the "green premium" in 2030 (when emissions may peak) and in 2060. Then we try to answer two questions: (1) What will be the cost of zero carbon emissions in 2030 and 2060? (2) How will the "green premium" change from the current level? Answers to these questions can measure the effectiveness and feasibility of our recommended technological roadmaps and policies.

\subsubsection{Zero Carbon Emissions Cost to be Rmb89.7bn in 2030, Implying a "Green Premium" of $2 \%$}

The estimation that the "green premium" in the transportation industry should be $2 \%$ in 2030 implies zero carbon emissions cost of Rmb89.7bn (Table 8.4), down about Rmb2.6trn from 2021 with around Rmb1.7trn (or 65\%) from the CV-based transport sector and about Rmb750bn (or about 29\%) from the PV-based transport sector.

The CV-based transport sector's zero carbon emissions cost is expected to decline Rmb1.7trn to Rmb242.3bn in 2030. Specifically, we estimate that the zero emissions cost of the HDT transport submarket will drop by Rmb1.5trn due to a combination of falling hydrogen cost $(-52 \%)$ and lower purchase price of hydrogen-powered HDTs $(-80 \%)$. We expect the zero emissions cost of the MDT and LDT transport submarkets to slide about Rmb180bn. In our view, the purchase price of electric 
Table 8.4 We expect the transportation industry's zero carbon emissions cost to be Rmb89.7bn in 2030

\begin{tabular}{l|l|l|l|l}
\hline 2030E & $\begin{array}{l}\text { Current energy } \\
\text { cost (Rmb bn) }\end{array}$ & $\begin{array}{l}\text { Cost after new } \\
\text { energy (Rmb bn) }\end{array}$ & $\begin{array}{l}\text { Cost of zero } \\
\text { carbon emission } \\
(\text { Rmb bn) }\end{array}$ & $\begin{array}{l}\text { Green premium } \\
(\%)\end{array}$ \\
\hline $\begin{array}{l}\text { Road transport } \\
\text { (freight) }\end{array}$ & 1,847 & 2,089 & 242 & 13 \\
\hline $\begin{array}{l}\text { Road transport } \\
\text { (passenger) }\end{array}$ & 3,493 & 3,159 & -333 & -10 \\
\hline Railway & 45 & 35 & -10 & -22 \\
\hline Aviation & 136 & 287 & 151 & 111 \\
\hline Shipping & 37 & 77 & 40 & 107 \\
\hline Total & 5,557 & 5,647 & 90 & 2 \\
\hline
\end{tabular}

Source CICC Research

MDTs and LDTs will decline 38\%, pushing down their lifecycle cost. We estimate that per-unit cost of electric MDTs and LDTs in 2030 would be $17 \%$ lower than the cost of those using traditional fuels (vs. a $7 \%$ premium in 2021).

The PV-based transport sector's zero carbon emissions cost will shrink about Rmb750bn to -Rmb333.5bn in 2030 with purchase price parity of pure electric PVs. As mentioned previously, we expect pure electric PVs to achieve purchase price parity with traditional fuel PVs in 2025 and per-unit electricity cost to be $60 \%$ lower than gasoline cost. The full lifecycle cost of pure electric PVs in 2030 (Rmb0.47/km) will be $10 \%$ lower than that of traditional fuel PVs (Rmb0.53/km). And this sector's zero emissions cost will be around -Rmb333.5bn.

\subsubsection{The "Green Premium" to Be 2\% in 2060, but Zero Carbon Emissions Cost to Drop to Rmb70.1bn}

The "green premium" in the transportation industry will be $2 \%$ in 2060 , implying zero carbon emissions cost of Rmb70.1bn (Table 8.5). The "green premium" in the PV-, $\mathrm{CV}$ - and railway-based transport sectors are expected to be all zero in 2060 due to full penetration of new energy. In contrast, the aviation and marine transportation sectors' zero carbon emissions cost will be Rmb53.7bn and Rmb16.4bn in 2060, implying a "green premium" of $18 \%$ and $31 \%$, as their energy demand cannot be fully met by new energy and per-unit hydrogen consumption cost should remain higher than fuel cost in 2060. Overall, the transportation industry's zero carbon emissions cost should be Rmb70.1bn in 2060, implying a "green premium" of $2 \%$.

Generally speaking, we think the "green premium" in the transportation industry will plunge from $68 \%$ in 2021 to $2 \%$ in 2060 , with the implied zero carbon emissions cost slipping from Rmb2.7trn in 2021 to Rmb89.7bn in 2030 and Rmb70.1bn in 2060. This indicates our recommended solutions are reasonable. Nevertheless, the "green premium" is unlikely to drop to zero in 2060, suggesting the transportation industry 
Table 8.5 We expect the transportation industry's zero carbon emissions cost to be Rmb70.1bn in 2060

\begin{tabular}{l|l|l|l|l}
\hline $2060 \mathrm{E}$ & $\begin{array}{l}\text { Current energy } \\
\text { cost (Rmb bn) }\end{array}$ & $\begin{array}{l}\text { Cost after new } \\
\text { energy (Rmb bn) }\end{array}$ & $\begin{array}{l}\text { Cost of zero } \\
\text { carbon emission } \\
\text { (Rmb bn) }\end{array}$ & $\begin{array}{l}\text { Green premium } \\
(\%)\end{array}$ \\
\hline $\begin{array}{l}\text { Road transport } \\
\text { (freight) }\end{array}$ & 1,530 & 1,530 & - & 0 \\
\hline $\begin{array}{l}\text { Road transport } \\
\text { (passenger) }\end{array}$ & 2,494 & 2,494 & - & 0 \\
\hline Railway & 55 & 55 & - & 0 \\
\hline Aviation & 298 & 352 & 53.7 & 18 \\
\hline Shipping & 52 & 69 & 16.4 & 31 \\
\hline Total & 4,429 & 4,499 & 70.1 & 2 \\
\hline
\end{tabular}

Source CICC Research

still requires more advanced technologies. The decline in the "green premium", to a large extent, relies on advances in LIB and hydrogen technologies. LIB technological roadmap remains visible, while development of hydrogen technology is uncertain and requires policy support for $\mathrm{R} \& \mathrm{D}$, adoption and criteria formulation.

\subsection{Outlook for Green Transportation: A Combination of Autonomous Vehicles, Super High-Speed Trains and Supersonic Aircraft}

We discussed the future based on visibility on technological development in previous sections. This section will picture the future of the transportation industry in 2060 that is 4 decades away from now. In the future predicted by us, modes of transportation in 2060 are very likely to include autonomous vehicles, hyperloop trains (super high-speed trains) and supersonic aircraft.

\subsubsection{Autonomous Driving: It Changes More Than Travel}

Autonomous driving requires highly effective coordination among vehicles, persons and the environment, and can complement normal driving under complicated conditions. 


\subsubsection{Autonomous Driving to Change Travel Habits and Significantly Improve Road Transport Efficiency}

The impact of complete autonomous driving on road transportation includes the following:

In the era of autonomous driving, vehicles will become the "third space" between home and office. Internal space in vehicles will be designed based on user needs to meet the comfort requirements from passengers. What's more, vehicles will become the "third space" instead of a means for travel, and passengers can work, relax and play inside vehicles.

Part of the travel demand will be diverted away from air and railway transportation to autonomous vehicles. For example, users in Beijing may sleep in an autonomous vehicle and arrive in Shanghai the next day.

Autonomous driving can effectively raise a vehicle's utilization rate and enhance transport efficiency. In our view, autonomous driving will promote PV sharing and raise utilization rate, and can help resolve safety problems such as driver fatigue and further enhance transport efficiency.

\subsubsection{Rising Penetration of Autonomous Driving to Produce a Profound Impact on Infrastructure Construction}

Autonomous driving will reshape the concept of road and promote the construction of multi-tiered underground tunnels. The era of autonomous driving will trigger large-scale construction of these tunnels. Autonomous vehicles can drive in tunnels with different depths, significantly enhancing road transport efficiency.

The demand for new parking lots will decline, saving urban land resources. Since autonomous driving will trigger the sharing economy in the area of travel, idle vehicles will no longer occupy parking space, and urban demand for parking lot construction will shrink considerably, thereby saving urban land resources.

\subsubsection{Can Hyperloop Trains be Realized?}

Hyperloop train is a mode of transport that Elon Musk proposed and is based on the theory of evacuated tube transportation. They have a number of advantages, such as high speed, low energy consumption, quietness and low pollution. The US and China have both made a big step in the R\&D of hyperloop trains. For example, Virgin Hyperloop in the US completed its first test ride with passengers in November 2020. China's Southwest Jiaotong University experimented with a hyperloop train with an hourly speed of more than $600 \mathrm{~km}$ in January $2021^{1.12}$

12 https://www.163.com/dy/article/G0831MQ20511NEUN.html (source in Chinese). 
If hyperloop trains are commercialized, they will reshape existing transportation systems and lifestyles.

Hyperloop trains have a faster theoretical speed than aircraft, and are very likely to affect the role of airplanes in long-distance travel. As a carbon-free mode of transport, hyperloop trains can help the transportation industry achieve carbon neutrality after replacing aircraft.

Moreover, we believe the development of hyperloop trains is very likely to redefine the concept of cities. For example, passengers in Shanghai might arrive in Beijing or Shenzhen in only 1 hour if they travel by hyperloop train. In other words, Beijing, Shanghai and Shenzhen would be as close to three places in a city.

The speed of hyperloop trains is amazing, and we believe supersonic aircraft with faster speeds are likely to be commercialized in the years ahead.

\subsubsection{Commercialization of Supersonic Aircraft Likely to Be in Sight}

Supersonic aircraft can travel at about $1,200 \mathrm{~km}$ per hour, which is faster than the speed of sound. Passenger and cargo aircraft have been subsonic for around 100 years since their inception. Yet fundamental changes are likely to take place in the coming years. Boom Supersonic released XB- $1,{ }^{13}$ the first supersonic demonstrator, in October 2020. According to its announcement, the test flight is set to take place in 2021, with the highest speed at $2,335 \mathrm{~km}$ per $\mathrm{h}$. The XB-1 can carry only two people, and is still only a demonstrator. The real bright spot is Boom Supersonic's Overture that can transport 55-75 people. Boom Supersonic expects Overture to be commercialized in 2025 .

Energy consumption by supersonic aircraft is more than double that of existing airplanes. Will they increase carbon emissions from the air transportation sector? Our analysis shows that they will not necessarily increase the emissions. XB-1's design, development and tests have all taken environmental impact into consideration. For example, when XB-1 is tested on the ground, $80 \%$ of the fuel consumed is clean fuel. If clean fuel applications in supersonic aircraft prove viable, this will significantly reduce carbon emissions. Supersonic aircraft can shorten the travel time and may also help the air transportation sector achieve carbon neutrality.

\footnotetext{
${ }^{13}$ https://boomsupersonic.com/xb-1
} 
Open Access This chapter is licensed under the terms of the Creative Commons AttributionNonCommercial-NoDerivatives 4.0 International License (http://creativecommons.org/licenses/bync-nd/4.0/), which permits any noncommercial use, sharing, distribution and reproduction in any medium or format, as long as you give appropriate credit to the original author(s) and the source, provide a link to the Creative Commons license and indicate if you modified the licensed material. You do not have permission under this license to share adapted material derived from this chapter or parts of it.

The images or other third party material in this chapter are included in the chapter's Creative Commons license, unless indicated otherwise in a credit line to the material. If material is not included in the chapter's Creative Commons license and your intended use is not permitted by statutory regulation or exceeds the permitted use, you will need to obtain permission directly from the copyright holder.

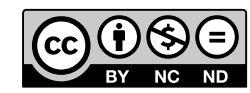

